\title{
Pandemiczny obraz świata dziecka zatraconego w telewizyjnej rzeczywistości
}

\begin{abstract}
A Pandemic View of the World of a Child Lost in Television Reality
The following article is aimed to increase reader knowledge about the most popular cartoons among children at the age of 5-9 and the values that occur in them. It describes how the pandemic affected on children real time which they were spending in front of the television. The first part of the article is a description of value and cartoon terms. The next section is a summary of research conducted with children in the form of an interview relating to the cartoons. Follow-up of the paper contains information about time spending in front of the television among children before and during the pandemic. In the further part, titles of the most popular cartoons among children was presented. Successive part showed analysis of the several fairy tales in terms of their plot and worth appeared in them. The last part of the article contains conclusions of the paper.
\end{abstract}

Keywords: values, moral values, fairy tales, television, pandemic

Słowa kluczowe: wartości, wartości moralne, bajki, telewizja, pandemia

\section{Wstęp}

Kontakt $\mathrm{z}$ rówieśnikami i przebywanie $\mathrm{w}$ środowisku szkolnym jest niezbędne do odpowiedniego rozwoju dziecka w każdym jego obszarze. Właśnie tam może ono doświadczać zachowań złych i dobrych, przez co uczy się dokonywania ich krytycznej oceny. W sytuacji pandemicznej wszystko to uległo zmianie.

Przez ostatnie lata bajki telewizyjne cieszą się niesłabnącym zainteresowaniem dzieci w młodszym wieku szkolnym i przedszkolnym. Izolacja społeczna i konieczność uczenia się w warunkach zdalnych sprawiła, że dla wielu dzieci codzienność wpasowała się $\mathrm{w}$ internetową i telewizyjną rzeczywistość, a bajki i programy telewizyjne stały się jednym z głównych źródeł informacji i rozryw- 
ki. $\mathrm{Z}$ zaskakująco trudnym zadaniem mierzą się również rodzice i nauczyciele pracujący w sposób zdalny, którzy zadają sobie pytania:

- Jakie bajki/materiały filmowe wybrać dla dziecka lub wychowanka?

- Które z nich przekazują odpowiednie treści i wartości?

- Ile czasu dziecko może spędzać przed ekranem telewizora?

Odpowiedzi na powyższe pytania nie są proste, zwłaszcza dla rodzica, który nierzadko nie jest w stanie wygospodarować czasu, aby oglądać każdą nową bajkę, która zainteresowała młodego widza.

Dzieci w wieku 5-9 lat w stworzonym przez Heliodora Muszyńskiego (1983) schemacie rozwoju moralnego są $\mathrm{w}$ jego drugim stadium o nazwie heteronomia moralna. Występujące w tym studium fazy to egocentryzm i konformizm moralny. Pierwsza z nich trwa zazwyczaj do piątego roku życia. Dziecko unika konfrontacji z problemem i karą, nie rozumie i nie analizuje sposobu postępowania ludzi go otaczających, a jego głównym celem jest zaspokajanie własnych potrzeb. Druga faza przypada na lata 5-9. Dziecko odczuwa niesłabnącą potrzebę uznania ze strony innych. Podejmuje się różnorodnych czynów, byle być podziwianym i zauważanym, choć niektóre jego zachowania mogą być nieakceptowalne. Objawia się to również przez silną identyfikację z bajkowym bohaterem. Kiedy dziecko widzi, że jego ulubiona postać jest wychwalana ze względu na swoje czyny, często niestosowne, pragnie postępować podobnie, gdyż oczekuje podziwu. Preferencje dzieci skupiają się na bajkach telewizyjnych z uwagi na ich atrakcyjność związaną z łatwym odbiorem oraz przyzwyczajeniami (Izdebska, 2001). W obecnej sytuacji obserwowanie zachowań innych dzieci, ocena oraz porównywanie ich z własnym postępowaniem nie są możliwe. Kontakt $\mathrm{z}$ rówieśnikami został w większości ograniczony jedynie do widzenia się przez kamerki internetowe, a w przypadku młodszych dzieci i ta forma nie zawsze była dostępna. Dzieci w takiej codzienności nie mogą odpowiednio kształtować systemu wartości. Źródłem postaw i zachowań staje się dla nich rodzina, ale też programy telewizyjne. Często zdarza się, że główną rolę w kształtowaniu się systemu wartości młodego widza przejmuje telewizja, która nierzadko przekazuje mu błędny obraz rzeczywistości.

Analiza badań przeprowadzonych przez firmę Media Group ukazuje, jak bardzo wzrosła oglądalność kanałów dziecięcych podczas pandemii. Badania prowadzone są od 2018 r., dzięki czemu można porównać oglądalność tych kanałów w latach poprzedzających pandemię z okresem, w którym się ona rozpoczęła. Od zamknięcia szkół w związku z pandemią dzieci oglądają więcej telewizji niż wcześniej. Czas spędzany przez nie przed ekranem wzrósł średnio o $18 \%$ i choć powoli maleje, to wciąż jest na poziomie znacznie wyższym niż w ubiegłych latach (Pełka, 2020). Badaniem objęto dzieci w wieku 4-12 lat.

Przedstawione dane wyraźnie ukazują, że czas spędzany na oglądaniu telewizji gwałtownie wzrósł, gdy ograniczono możliwość wychodzenia z domów w 2020 r. Pandemia zmieniła model konsumpcji mediów. Dotyczy to szczegól- 

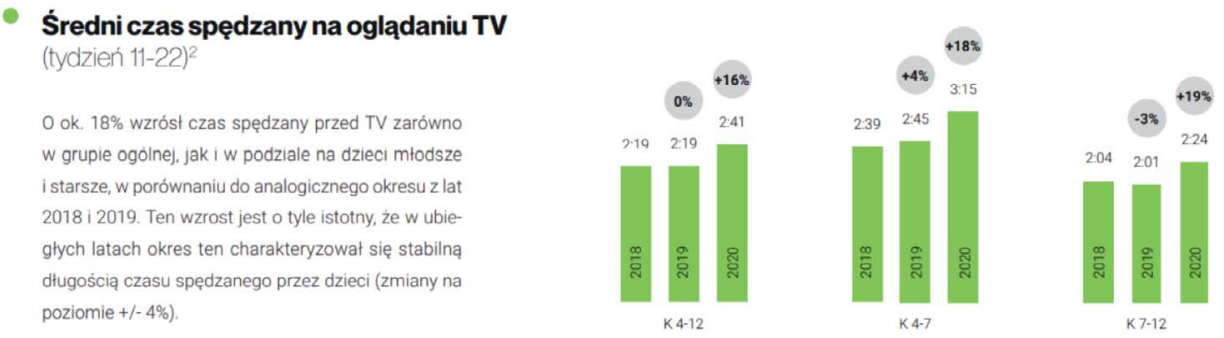

Średni czas spędzany na oglądaniu telewizji. Źródło: Pełka, 2020, s. 2

nie dzieci w wieku 4-12 lat, które w analizowanym okresie spędzały przed telewizorem blisko o jedną piątą czasu więcej. Zamknięcie przedszkoli i szkół wpłynęło także na to, że została zatarta różnica pomiędzy intensywnością oglądania telewizji w dni robocze i weekendy (Pełka, 2020).

\section{Rozumienie terminów „wartość” oraz „bajka”}

Definicje wartości w literaturze przedmiotu bywają różnorodne. Najczęściej można spotkać się ze stwierdzeniem, że „wartości to zdrowie i uroda, rodzina i wykształcenie, mądrość, bezpieczeństwo, dobra muzyka czy kariera. To, co jest dla nas ważne i cenne" (Olszewska, Koźmińska, 2007). Autorki definicji wyróżniły kluczowe wartości moralne w kształtowaniu się systemu wartości każdego człowieka: szacunek, uczciwość, odpowiedzialność, odwaga, samodyscyplina, pokojowość, sprawiedliwość, szczęście oraz optymizm i humor, przyjaźn i miłość, solidarność, piękno, mądrość.

Kultura, obok domu rodzinnego i środowiska szkolnego, ma ogromny wpływ na kształtowanie się systemu wartości u młodych ludzi. Dostęp do telewizji i ciekawość dzieci często sprawia, iż oglądają one kanały nieprzeznaczone dla nich. Dzieciom towarzyszą nie tylko bajki, ale też programy przyrodnicze, teleturnieje, programy sportowe czy filmy skierowane do starszej publiczności. Treści przekazywane w wybranych programach często pełne są scen brutalnych, katastroficznych lub o zabarwieniu erotycznym, które bez odpowiedniego komentarza mogą być dla dziecka szkodliwe.

Aby poprawnie ukierunkować dziecko na kształtowanie odpowiednich wartości, należy wiedzieć, jak możemy je podzielić oraz które z bajek mogą nam w tym pomóc, a które nie. Należy pamiętać, że wartości przejawiają się zarówno w naszych czynach, jak i w czynach ulubionych bajkowych bohaterów. Mają one również istotny wpływ na jakość życia każdego z widzów, zwłaszcza na dziecko, które, dorastając, kształtuje swój system wartości oraz samego siebie jako członka pewnej społeczności. 
Bajką można nazwać:

[...] opowiadanie oparte na treściach fantastycznych, często zaczerpniętych z legend, przeznaczone dla dzieci w wieku przedszkolnym i wczesnoszkolnym, a czasami także dla dorosłych. Bajka zaznajamia dzieci z uniwersalnymi wartościami prawdy, dobra, piękna, uwrażliwia na niesprawiedliwość, rozbudza wyobraźnię, zaspokaja potrzebę marzeń i fantazjowania. Poprzez zawarty w niej morał — przesłanie wzbogaca życie wewnętrzne dziecka i sprzyja jego samodoskonaleniu, a dzięki temu, że zawsze dobrze się kończy, budzi w nim wiarę w dobro. Wykazano, że systematyczne czytanie i opowiadanie bajek wpływa korzystnie na rozwój umysłowy, uczuciowy i wolicjonalny dzieci. Charakterystyczną cechą bajek są dobitne przeciwstawienia: postacie mogą być krańcowo dobre/złe, mądre/głupie, pracowite/leniwe (C. Kupisiewicz, M. Kupisiewicz, 2009, s. 17).

Zmiana podejścia do wychowania i łatwy dostęp do nośników medialnych sprawia, że dzieci coraz częściej — zamiast słuchać czytanych bajek — oglądają ich animowane wersje. Często mówi się, że „wszystko jest dla ludzi”, ale należy na to patrzeć $\mathrm{z}$ odpowiednim dystansem i znaleźć w tym wszystkim umiar. Warto podchodzić do bajek w sposób krytyczny i w miarę możliwości poznawać je razem $z$ dzieckiem. Baśń wychowuje bowiem inaczej niż rodzice - nie nakazami i zakazami, ale ukazując wzory i ideały. Przygotowuje dzieci do życia, tworząc w ich psychice swoiste aksjologiczne rusztowanie. Dziecko, które nie doświadczy literackiej inicjacji zła i strachu, będzie całkowicie bezradne wobec własnych lęków (Szkolak-Stępień, 2019).

\section{Badania własne}

Z końcem 2019 r. i tuż przed wybuchem pandemii wykonano badanie, w którym wzięło udział łącznie 35 dzieci w wieku 5-9 lat. W celu porównania danych badanie ponowiono tuż przed dwutygodniową przerwą $\mathrm{w}$ pracy stacjonarnej przedszkoli, wprowadzoną w dniu 26 marca 2021 r. Objęto nim 15 dzieci w wieku 5-6 lat.

Badanie polegało na przeprowadzeniu wywiadu $z$ dziećmi na temat najczęściej oglądanych bajek telewizyjnych, występujących w nich bohaterów dobrych i złych, określeniu więzi emocjonalnej z daną postacią oraz dokonaniu próby odnalezienia $\mathrm{w}$ wybranych animacjach wartości. W badaniu posłużono się metodą jakościową, a konkretniej; jakościową analizą tekstu. Podczas rozmów prowadzonych $z$ dziećmi notowano najważniejsze informacje przez nie podawane, w tym tytuły bajek, które następnie zostały dokładnie przeanalizowane pod kątem wartości w nich występujących oraz zachowań przejawianych przez najczęściej wymienianych bajkowych bohaterów. Przeprowadzonym badaniom przyświecały następujące cele: zbadanie, jakie bajki dzieci oglądają najchętniej oraz jakie ukazują one wartości i w jaki sposób. 
Rozmawiając o dzieciach i z dziećmi, odrzucono kilka wartości wymienionych w części teoretycznej, a mianowicie: pokój, sprawiedliwość, solidarność i samodyscyplina, które dla dzieci w wieku 5-9 lat są pojęciami abstrakcyjnymi, co sprawia, że nie były one $\mathrm{w}$ stanie zrozumieć ich znaczenia, a przede wszystkim odnaleźć ich w bajkach. Podczas badania posłużono się metodą dialogową oraz metodą analizy dokumentów. W czasie wywiadów poruszono temat zarówno bajek, jak i wartości, aby pomóc dzieciom wyróżnić je w wymienianych przez nie pozycjach. Dzieci, zapytane o to, czym są wartości, często wymieniały przedmioty materialne, lecz już dzieci siedmioletnie w swoich odpowiedziach jako najważniejsze wartości wymieniały rodzinę i przyjaciół. Jako narzędzie badawcze posłużył kwestionariusz wywiadu. Zawierał on pytania otwarte, które zadawano dzieciom podczas rozmów.

\section{Czas spędzany przed odbiornikiem telewizyjnym przed i w czasie pandemii}

Częstym zjawiskiem $\mathrm{w}$ relacji dziecka $\mathrm{z}$ telewizorem jest swoboda wyboru programów, ale równie często rodzice nie kontrolują czasu dziecka spędzanego przed telewizorem. Jest to powszechne zjawisko, zwłaszcza gdy dzieci zmuszone są do ciągłego przebywania $\mathrm{w}$ domach $\mathrm{w}$ związku sytuacją pandemiczną. Dzieci, pozbawione możliwości uczestniczenia w stacjonarnym trybie nauczania, zostały postawione przed ogromnym wyzwaniem, jakim jest organizacja własnego czasu i zdalnej nauki. Przebywając $\mathrm{w}$ domu, mają dostęp do licznych dystraktorów, którym muszą się opierać, aby aktywnie uczestniczyć w zdalnych zajęciach. Jedynym $z$ nich jest właśnie telewizja. Po przeprowadzeniu rozmów z dziećmi przedszkolnymi, które od 29 marca 2021 r. ponownie nie mogły uczestniczyć w stacjonarnym nauczaniu, jak to miało miejsce już rok temu, ustalono, ile czasu spędzały, oglądając telewizję, dotychczasEW i jak to według nich będzie wyglądało, gdy będą czas spędzać w środowisku domowym. Dzieci na podstawie swoich doświadczeń stwierdzały, że:

- Bajki oglądają podczas każdego posiłku.

- Towarzyszą im one po przebudzeniu się oraz przed zaśnięciem.

- Kreskówki służą im jako rozrywka podczas wizyt rodzinnych, np. u dziadków.

- Jedno z dzieci zaryzykowało stwierdzenie, że podczas dwutygodniowej przerwy w pracy stacjonarnej przedszkola „rozpłynie się od bajek”, co następnie wyjaśniło w ten sposób, że będzie ich oglądać bardzo dużo. 


\section{Najpopularniejsze bajki wśród dzieci pięcio-dziewięcioletnich}

Dzieci uczestniczące w badaniu bardzo chętnie odpowiadały na zadawane pytania, $z$ ogromnym entuzjazmem opowiadały o przygodach swoich ulubionych bajkowych bohaterów oraz o tym, co działo się w ostatnim oglądanym odcinku. Niektórym z nich trudność sprawiło odnajdywanie wartości w danej bajce, ale po krótkim zastanowieniu się ilustrowały to przykładami bajkowych sytuacji. Przytoczę tu odpowiedź była wypowiedź ośmioletniej Ani, w której to opisała ona postać Pana Kraba, bohatera kreskówki Spongebob Kanciastoporty. Opisała sytuację, w której wspomniana postać była tak przywiązana do pieniędzy, że oszukiwała swojego naiwnego pracownika i przyjaciela Spongeboba, często nie płacąc mu za pracę lub dając mu w zamian coś niewiele wartego. Aby lepiej przybliżyć wartości w wymienianych przez dzieci bajkach, przedstawiano tabele prezentujące tytuły wybranych przez nie bajek.

Liczba tytułów wskazanych przez uczestników badania skłania ku refleksji, iż dzieci oglądają bardzo wiele bajek i spędzają przed telewizorami dużą część swojego wolnego czasu.

Najczęściej wymieniane przez uczestników tytuły:

1. Psi Patrol

2. Kraina Lodu

3. Spongebob Kanciastoporty

4. Lego Ninjago

5. Pokemony

6. Vaiana

7. Transformers: Rescute Bots

8. My Little Pony

9. iCarly

10. Niebezpieczny Henryk

11. Dzieciak rzaddzi

12. Niesamowity świat Gumballa

13. Niech żyje król fulian

14. Barbie: W świecie gier

15. Młodzi Tytani: Akcja!

16. Supa Strikars

Porównując wyniki sprzed i po wybuchu pandemii, można wnioskować, iż preferencje młodych widzów nie uległy znaczącym zmianom. 
Tabela 1. Bajki wybierane przez dzieci w wieku przedszkolnym

\begin{tabular}{|c|c|c|}
\hline \multirow[t]{2}{*}{ Tytuł bajki/programu } & \multicolumn{2}{|c|}{ Liczba oglądających ją dzieci } \\
\hline & $\begin{array}{l}\text { Wyniki uzyskane } \\
\text { przed pandemią }\end{array}$ & $\begin{array}{c}\text { Wyniki uzyskane } \\
\text { po roku trwania pandemii }\end{array}$ \\
\hline Psi Patrol & 9 & 2 \\
\hline Transformers: Rescue Bots & 2 & - \\
\hline My Little Pony & 2 & 1 \\
\hline Kraina Lodu & 2 & 3 \\
\hline iCarly & 2 & - \\
\hline Księżniczka Zosia & 1 & - \\
\hline Stacyjkowo & 1 & - \\
\hline Masza i niedźwiedź & 1 & 1 \\
\hline Zaplatani: Przygody Roszpunki & 1 & - \\
\hline Eowcy trolli & 1 & - \\
\hline Agent Kot & 1 & - \\
\hline Mata syrenka & 1 & - \\
\hline Samoloty & 1 & - \\
\hline Supa Strikars & 1 & - \\
\hline Spongebob Kanciastoporty & - & 2 \\
\hline Vaiana: Skarb oceanu & - & 2 \\
\hline Lego Ninjago & - & 3 \\
\hline Pokemony & - & 2 \\
\hline Gigantozaur & - & 1 \\
\hline Batman & - & 1 \\
\hline Vampirina & - & 1 \\
\hline Gormitti & - & 1 \\
\hline Clifford & - & 1 \\
\hline Harry Potter & - & 1 \\
\hline
\end{tabular}

Opracowanie własne. 
Tabela 2. Bajki i programy wybierane przez uczniów klas I-III

\begin{tabular}{|c|c|}
\hline Tytuł bajki/programu & $\begin{array}{c}\text { Liczba uczniów, } \\
\text { którzy wskazali poszczególny tytuł }\end{array}$ \\
\hline Kraina lodu & 7 \\
\hline Niebezpieczny Henryk & 6 \\
\hline Dzieciak rzadzi & 4 \\
\hline Niesamowity świat Gumballa & 3 \\
\hline Niech żyje Król Fulian & 3 \\
\hline Barbie: W świecie gier & 3 \\
\hline Młodzi Tytani: Akcja! & 3 \\
\hline Supa Strikars & 2 \\
\hline Grzmotomocni & 1 \\
\hline Fedenastka & 1 \\
\hline Fak wytresować smoka & 1 \\
\hline Masza i niedźwiedź & 1 \\
\hline Miraculum: Biedronka i Czarny Kot & 1 \\
\hline Spongebob Kanciastoporty & 1 \\
\hline Kopciuszek & 1 \\
\hline Alvin $i$ wiewiórki & 1 \\
\hline Fineasz $i$ Ferb & 1 \\
\hline Angry Birds & 1 \\
\hline Toy Story & 1 \\
\hline Game Shakers & 1 \\
\hline Vaiana: Skarb oceanu & 1 \\
\hline Grinch & 1 \\
\hline Wodogrzmoty Mate & 1 \\
\hline Sam i Cat & 1 \\
\hline Sing & 1 \\
\hline Mia i Biaty Lew & 1 \\
\hline Marta mówi & 1 \\
\hline Domisie & 1 \\
\hline Nicky, Ricky, Dicky i Dawn & 1 \\
\hline Merida Waleczna & 1 \\
\hline Fessie & 1 \\
\hline Lego przygoda & 1 \\
\hline Shrek & 1 \\
\hline Magiczne magimiecze & 1 \\
\hline Wojownicze żótwie Nija & 1 \\
\hline Fineasz $i$ Ferb & 1 \\
\hline Prawo Milo Murphy'ego & 1 \\
\hline Pokemony & 1 \\
\hline
\end{tabular}

Opracowanie własne. 
Tabela 3. Wartości przekazywane przez wybrane bajki

\begin{tabular}{|l|l|}
\hline Tytuł bajki & Wartości przekazywane przez tę bajkę \\
\hline Psi Patrol & przyjaźń, wiara, spokój, odwaga, mądrość \\
\hline Kraina Lodu & odwaga, rodzina, miłość, przyjaźń, mądrość, optymizm \\
\hline Transformers: Rescute Bots & $\begin{array}{l}\text { odwaga, sprawiedliwość, odpowiedzialność, prawda, } \\
\text { przyjaźń, rodzina }\end{array}$ \\
\hline My Little Pony & przyjaźń, dobro, sprawiedliwość, odwaga, spokój. \\
\hline iCarly & przyjaźń, miłość, rodzina, brak szacunku \\
\hline Niebezpieczny Henryk & mądrość, przyjaźń, odwaga, brak szacunku \\
\hline Dzieciak rządzi & $\begin{array}{l}\text { rodzina, miłość, pokojowość, humor, mądrość, solidar- } \\
\text { nośc, przyjaźń }\end{array}$ \\
\hline Niesamowity świat Gumballa & $\begin{array}{l}\text { nieodpowiedzialność, odwaga, tchórzostwo, strach, } \\
\text { przyjaźń, mądrość, miłośc, humor }\end{array}$ \\
\hline Niech żyje król fulian & rodzina, przyjaźń, mądrość \\
\hline Barbie: W świecie gier & mądrość, samodyscyplina, przyjaźń, piękno, odwaga \\
\hline Młodzi Tytani: Akcja! & mądrość, samodyscyplina, przyjaźń, piękno, odwaga \\
\hline Supa Strikars. & mądrość, samodyscyplina, przyjaźń, piękno, odwaga \\
\hline
\end{tabular}

Opracowanie własne

\section{Wartości występujące w wybranych bajkach telewizyjnych}

Osobom, które nie są zainteresowane tematyką bajek, na pewno wiele tytułów - jeśli nie wszystkie - wydaje się obcych. Podczas badań dokonano wnikliwej analizy każdej z wymienionych 12 . Na samym początku dokonano ogólnej analizy przez rozmowy $\mathrm{z}$ dziećmi, a następnie zapoznano się $\mathrm{z}$ wybranymi odcinkami seriali bajkowych lub całością filmów animowanych. Analiza była na tyle dokładna, iż pozwoliła odczytać wartości ukryte w poszczególnych bajkach oraz sposób ich przedstawiania, często nieadekwatny i niepoprawny. Wyniki przeprowadzonej analizy ilustruje tabela 3.

Porównanie powyższych danych prowadzi do wniosku, iż najczęściej występującą wartością we wskazanych bajkach jest przyjaźn, następnie: odwaga, miłość, mądrość, rodzina, a znacznie rzadziej wskazywana jest sprawiedliwość, odpowiedzialność, samodyscyplina, dobro, pokojowość, humor i piękno. Należy zauważyć, że respondenci nie wskazywali jedynie bajek przeznaczonych dla dzieci w ich wieku. Można zaobserwować też tytuły, które zaadresowane są do 
dzieci w wieku powyżej 12 lat, a nawet dla dorosłych odbiorców. Seriale komediowe, takie jak Niebezpieczny Henryk czy iCarly, przedstawiają świat dorosłych, a bohaterowie ukazywani są w sposób realistyczny. Nie jest to rzeczywistość bajkowa, fantastyczna. Dzieci oglądające wymienione programy, a również inne, które były wskazywane już przez dzieci pięcioletnie, zamiast poznawać świat, który odpowiada ich dziecięcemu poziomowi rozwoju, zapoznają się ze światem dorosłych i jego problemami.

Czym więc kierują się dzieci wybierając programy telewizyjne? W ich odpowiedziach często pojawiały się stwierdzenia, iż wybrały daną bajkę, ponieważ:

- Bohaterowie bajki są odważni, uśmiechnięci i mili.

- Postaci występujące w danej bajce mają magiczne moce czy umiejętność latania, które uczestnicy badania chcieliby przenieść do świata realnego.

- Często pojawiała się odpowiedzieć, iż dany bohater jest zabawy i niesforny, czym przysparza rodzicom wiele kłopotów. Dzieci uzasadniały to tym, że również chciałyby bezkarnie rozrabiać.

- Młodsze dzieci sugerowały się również kolorem danej postaci, jej ubiorem i pięknem sylwetki.

- Dzieci wskazywały na różne przygody bajkowych bohaterów i ich odwagę w pokonywaniu.

- Kolejnym ważnym dla dzieci aspektem był humor w danej bajce, mówiły o tym, iż bohaterowie są zabawni i zawsze uśmiechnięci, co sprawia, że same są w dobrym humorze.

Pytane o to, czy chciałyby wcielić się w któregoś z wymienionych przez siebie bohaterów, w większości odpowiadały twierdząco. Znaczy to, że utożsamiają się z ulubionymi bajkowymi bohaterami. Najbardziej podziwianymi bohaterami przez uczestników badania były następujące postacie: Elsa i Anna - bohaterki Krainy Lodu; Skye i inne postaci z Psiego Patrolu; postacie z kreskówki Spongebob Kanciastroporty, w tym tytułowy bohater oraz jego przyjaciel Patryk Rozgwiazda; sławny piłkarz Shaker, występujący w bajce Supa Strikars; niesforna Masza - tytułowa bohaterka bajki Masza i niedźwiedź.

Dzieci, które mają swobodę w wyborze oglądanych treści, wybierają najczęściej filmy, które charakteryzują się szybkością akcji oraz wesołym usposobieniem bohaterów. Istotna jest też płeć, ponieważ okazuje się, że chłopcy preferują filmy o chłopcach, a dziewczynki chciałyby oglądać filmy, w których występują dziewczynki (Kielar, 1978). 


\section{Wnioski}

Opierając się na rozmowach $\mathrm{z}$ dziećmi oraz przeprowadzonych badaniach, zaobserwowano wielość tytułów wybieranych przez dzieci, co związane jest z bardzo bogatą ofertą kanałów dziecięcych. Liczba programów wskazuje również na ogromne zainteresowanie bajkami wśród dzieci, gdyż każde z nich ma możliwość odnalezienia czegoś, co zaspokoi jego potrzeby i będzie odpowiadało jego zainteresowaniom. Wiele tych bajek przekazuje istotne treści oraz pomaga młodym widzom konstruować własny system wartości. Nie zawsze jednak się tak dzieje, ponieważ dzieci oglądają również produkcje, które nie są do nich zaadresowane. Wyniki przeprowadzonych badań i analiza bajek dowodzą, iż każda $z$ nich przekazuje wartości, lecz niektóre $\mathrm{z}$ nich promują takie, które nie mieszczą się w systemie preferowanym przez rodzinę i szkołę. Istotną rolę mają tu do odegrania opiekunowie dzieci, których powinnością jest czuwanie nad dobrem dziecka i odpowiednim doborem programów telewizyjnych, dziecko w młodszym wieku nie jest bowiem jeszcze zdolne do oceny bajek i wyboru tych, które są wartościowe, a dzieci mają preferencje doboru telewizyjnego repertuaru odmienne niż ich opiekunowie.

\section{Zakończenie}

W tym jakże trudnym czasie należy nie tylko czuwać nad tym, co dziecko ogląda, ale również sprawdzac ile czasu spędza przed odbiornikiem telewizyjnym. Dane statystyczne wskazują na drastyczny wzrost czasu spędzanego przez dzieci na oglądaniu bajek. Może na tym ucierpieć nie tylko ich rozwój fizyczny, ale zniekształceniu może też ulec jego kształtujący się system wartości. Moment zakończenia izolacji społecznej spowodowanej pandemią nie jest określony.

W tym okresie niezwykle istotna jest rola rodziców. Powinni oni skupić się na szczegółowej analizie bajek oglądanych wspólnie z dzieckiem, aby móc dokonać doboru odpowiednich treści. Rozwój dziecka jest bardzo ważny i nie powinno zaniedbywać się go ze względu na izolację. Warto ten wspólnie spędzany czas wykorzystać jak najlepiej. 


\section{Bibliografia}

Izdebska, J. (2001). Rodzina, dziecko, telewizja. Szanse wychowawcze i zagrożenia telewizji. Białystok: Trans Humana.

Kielar, M. (1978). Rola filmu anonimowego w pracy wychowawczo-dydaktycznej przedszkola. Warszawa: WSiP.

Kupisiewicz, C., Kupisiewicz, M. (2019). Stownik pedagogiczny. Warszawa: PWN.

Muszyński, H. (1983). Rozwój moralny. Warszawa: WSiP.

Olszewska, E., Koźmińska, I. (2007). Z dzieckiem w świat wartości. Warszawa: Świat Książki.

Pełka, K. (2020). Pandemia a oglądalność kanatów dziecięcych. Analiza Media Group. Warszawa: Analizy Media Group.

Stachura, K. (2020). Wartości przekazywane przez wspótczesne bajki ogladane przez dzieci w wieku 5-9 lat. [Niepublikowana praca licencjacka napisana pod kier. C. Grzywniak]. Kraków: UP.

Szkolak-Stępień, A. (2019). Terapeutyczna moc bajki. „Pedagogika Przedszkolna i Wczesnoszkolna”, 7, 2 (14), s. 7-15. 